\title{
Three New Species and One New Record of Genus Chimarra Stephens (Trichoptera: Philopotamoidea: Philopotamidae) from Indian Himalaya
}

\author{
Manpreet Singh Pandher ${ }^{1}$ and Simarjit Kaur ${ }^{2}$ \\ ${ }^{1}$ Department of Zoology, Desh Bhagat University, Mandi Gobindgarh, Punjab 147301, India \\ ${ }^{2}$ Department of Zoology \& Environment Sciences, Punjabi University, Patiala 147002, India \\ Correspondence should be addressed to Manpreet Singh Pandher; mpandher.iari@gmail.com
}

Received 2 April 2014; Accepted 30 June 2014; Published 21 July 2014

Academic Editor: Rick Hochberg

Copyright ( 92014 M. S. Pandher and S. Kaur. This is an open access article distributed under the Creative Commons Attribution License, which permits unrestricted use, distribution, and reproduction in any medium, provided the original work is properly cited.

\begin{abstract}
Three new species and one new record are added to the philopotamid fauna of India from the Indian Himalaya. The newly described species under the genus Chimarra Stephens include Chimarra butticulata sp.n. and C. gangotriensis sp.n. both from Uttarakhand and C. sangtami sp.n. from Nagaland. The record of C. nigra Kimmins (from Sikkim) constitutes the first record of that species from India, although it was previously known from Nepal. It is redescribed here from India as there are minor differences in the male genitalia from previously described species (in original paper of Kimmins only lateral view of the phallus was illustrated and in the redescribed species the ventral view of phallus is illustrated along with the lateral view). The four species belong to two different species groups and one species is unplaced in the species group. These species are distinguishable from each other as well as from the previously known allied species by consistent taxonomic features of the inferior appendages, tergite $\mathrm{X}$, and the phallic apparatus of males.
\end{abstract}

\section{Introduction}

With more than 800 species known for the world, about 400 species of the genus Chimarra Stephens are recorded from the Oriental Region [1]. The genus is the second largest caddisfly genus in terms of species diversity, second only to Rhyacophila [2] (Rhyacophilidae), and is known from all biogeographical regions except Antarctica [3]. About 2/3rd of the species in the genus Chimarra are restricted to the Oriental and Neotropical Regions and the lowest diversity (less than 3\% of the species) is in the Palaearctic Region.

The genus Chimarra is divided into 4 subgenera: Chimarra Stephens, Chimarrita Blahnik, Curgia Walker, and Otarrha Blahnik [4]. The last 3 subgenera occur only in the Neotropical Region, whereas subgenus Chimarra occurs worldwide and is especially abundant in tropical regions, being the only subgenus of the subfamily Chimarrinae distributed in India.

Most of the oriental species of Chimarra were described in the past 22 years. Malicky [5-18] described 162 species from Nepal, China, Cambodia, Thailand, Indonesia (Ambon, Bali, Irian Jaya, Java, Kalimantan, Lombok, Sulawesi, and Sumatra), Vietnam, Bhutan, Malaysia (Sabah), Pakistan, Philippines, Sri Lanka, and India (Andaman Islands, Great Nicobar Island, and South Andaman Island). In addition to those works coauthored by Malicky and others, in which many new species were described and first national species records made include those of Sun and Malicky [19], Malicky and Chantaramongkol [20-23] and Malicky et al. [24], other works describing Oriental species of Chimarra include those of Banks [25-27], Blahnik et al. [3, 28], Ghosh and Chaudhury [29], Hagen [30, 31], Hwang [32], Jacquemart [33], Kimmins [34-36], Martynov [37], Melnitsky [38], Mey [39-44], Mosely [45], Navás [46-48], Oláh [49], Oláh and Malicky [50], Saini et al. [51-53], Johanson and Oláh [54], Pandher and Saini $[55,56]$, Schmid [57, 58], Sun [59], Ulmer [60-65], Yang et al. [66], and Wang et al. [67].

Until now, 36 species of this genus have been recorded from India. Among these previously described species, 27 
have been reported only from the Himalayan region. Contributors to these species include Kimmins [35] (5 species), Martynov [37] (4 species), Ghosh and Chaudhary [29] (2 species), Saini et al. [51-53] (8 species), and Pandher and Saini $[55,56]$ (8 species), respectively. Four species were described from mountain springs of the Western Ghats (Maharashtra and Karnataka) by Navás [47] (3 species) and Kimmins [35] ( 1 species) and 4 species are reported from tropical rain forests of Andaman and Nicobar Island by Malicky $[5,10]$ (2 species; 2 species). Chimarra aberrans Martynov occurs in all regions of India and one species has been recorded from Mount Abu (Rajasthan) by Pandher and Saini [56].

\section{Materials and Methods}

The specimens were collected with light traps for 1-4 hours after dusk in 2009-2010 (April-October), using either 135 W, ultraviolet, mercury-vapour bulbs (with alternating current), or $22 \mathrm{~W}$ Circline fluorescent BL tubes (Bioquip, with 12volt, rechargeable batteries). The collection was made near the banks of the small streams, tributaries, and the main rivers originating from glaciers of the Indian belt of the Himalaya, with water quantity varying from shallow to deep and with slow to swiftly flowing waters. Genitalia were cleared in $10 \% \mathrm{KOH}$ solution overnight, then observed, and preserved with the remainder of the specimen in $80 \%$ ethyl alcohol with a drop of glycerol. Additional specimens were cleared using lactic acid method as proposed by Blahnik and Holzenthal [68] and Blahnik et al. [69]. Terminology for genitalia and wings corresponds to that of Blahnik [4] and Blahnik et al. [28] for Chimarra. Types of the new taxa are deposited in National Pusa Collection Museum (NPC), Indian Agricultural Research Institute New Delhi.

\subsection{Tsudai Group}

\subsubsection{Chimarra nigra Kimmins}

Chimarra nigra Kimmins 1964: 42 (Figure 1 (1)-(5))

Material Examined. India, Sikkim, Sangkalang, 1500 m, 13-v-2009 10; 1ㅇ, Pandher and Parey, (NPC).

Description. Adult ơ; body transparent light brown (in alcohol). Length of antenna-4 $\mathrm{mm}$; length from tip of head to apex of folded forewing $5 \mathrm{~mm}$.

Male Genitalia (Figure 1 (1)-(5)). Segment IX short; tergum IX short, anterodorsally produced, anterior margin concave, anteroventrally produced, posterolateral margin almost straight; posteroventral process well developed. Preanal appendages, each globular, obliquely placed in lateral view; setose and semicircular in dorsal view. Inferior appendages each directed posteriorly, as long as tergum $\mathrm{X}$, narrow basally, widened apicomesally in lateral view; in ventral view, broad basally, tapering apically, with pointed apex, slightly curved outward. Tergum X with sclerotized lateral lobe and obsolete membranous mesal lobes; each lateral lobe wedge-shaped mesoventrally pointed and bears multiple sensilla in lateral view; divergent, clavate, in dorsal view; each mesal lobe digitate, directed posterodorsally in lateral view; convergent, digitate in dorsal view. Phallotheca tubular, expanded basodorsally, and sclerotized; endotheca tubular, constricted mesodorsally in lateral view, bearing granular area at apex, length not discernable, and no endothecal spine and phallotremal sclerite complex visible in either views.

Distribution. Nepal. India: Sikkim.

Diagnosis. This species is allied to Chimarra berenike Malicky [11] and C. argeia Malicky and Chantaramongkol [70] in the shape of segment IX in lateral view. However, narrow and small lateral lobe of tergum $\mathrm{X}$ and the inferior appendage with rounded apex in lateral view set this species aside from allied species.

\section{Chimarra butticulata sp.n. (Figure 1 (6)-(10))}

Material Type. Holotype. India. o: Uttarakhand, Maneri, $1200 \mathrm{~m}$, 5-vi-2009, Pandher and Parey, (NPC). Paratype. $2 \sigma^{\star}, 1$, , collection data the same as that of holotype (NPC).

Etymology. This species name is derived from Latin word "butticula" which means bottle or pitcher, based on the bottle like lateral lobes of tergum $\mathrm{X}$ in dorsal view.

Description. Adult ơ; color in alcohol dark brown, dorsum of head dark brown, antenna dark brown, maxillary palp brownish. Length from tip of head to apex of folded forewing about $5.75 \mathrm{~mm}$; maxillary palp-1.25 mm long; 3rd segment longer than 2nd but subequal to 5 th; labial palp $-0.75 \mathrm{~mm}$ long. Length of each forewing $5 \mathrm{~mm}$; Rs thickened, curved; cross vein $m$ in close proximity of $s$ and $r-m$ cross veins; $2 \mathrm{~A}$ obsolete apically, looped to $1 \mathrm{~A}$ at cross vein $a$; hind wing about $3.50 \mathrm{~mm}$ long.

Male Genitalia (Figure 1 (6)-(10)). Tergum IX very short, anterodorsally produced; anterior margin concave; anteroventrally produced; posterolaterally mesally produced; posteroventral process poorly developed. Preanal appendages, each small, setose, semicircular in lateral view, rounded in dorsal view. Inferior appendages, each longer than tergum $\mathrm{X}$, directed posterad, narrow at base, wide mesally tapering apically and rounded at apex in lateral view; in ventral view uniformly wide at base, tapering to apex, with pointed, dark, mesally curved apex. Tergum X with sclerotized lateral and mesolateral lobes and obsolete mesal membranous lobes; each lateral lobe long, wide, curved downward, pointed at apex and lobe bearing multiple sensilla in lateral view; in dorsal view wide basally up to middle, gradually narrowing towards apex; each mesolateral lobes digitate almost half the length of lateral lobes in dorsal view, curved upward in lateral view. 


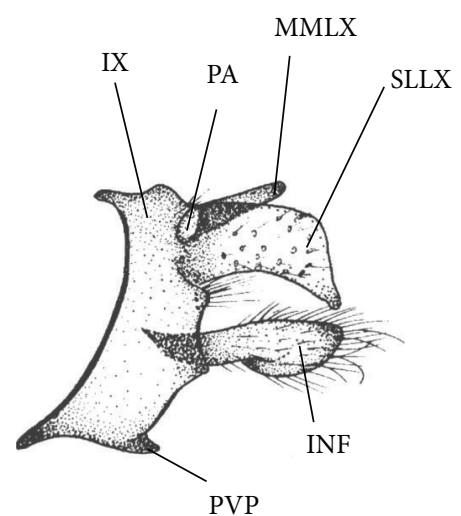

(1)

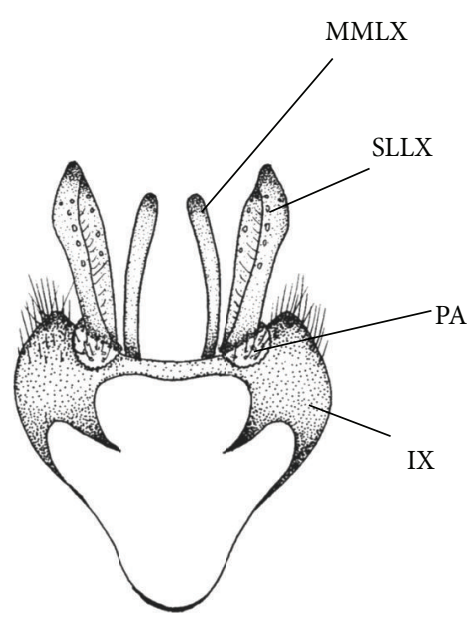

(2)

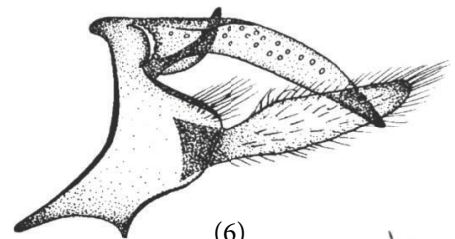

(6)

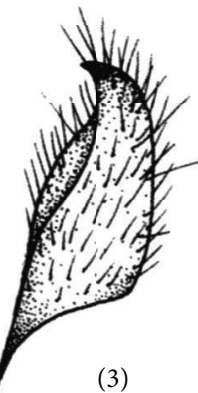

(3)

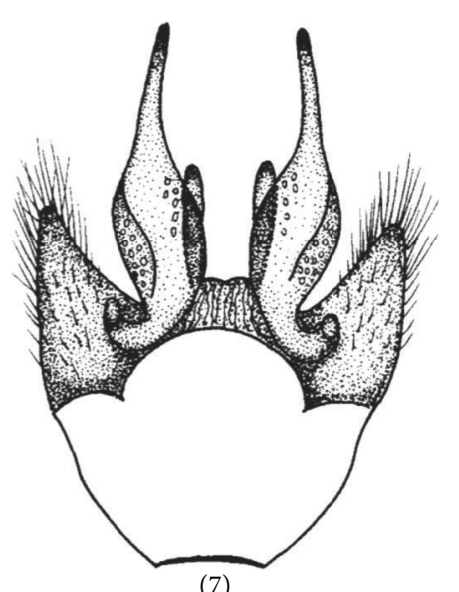

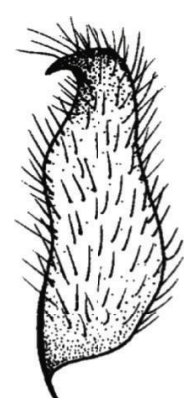

(8)

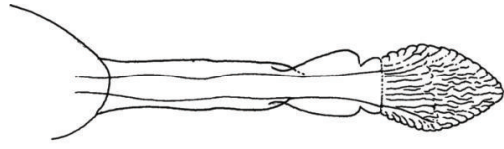

(4)

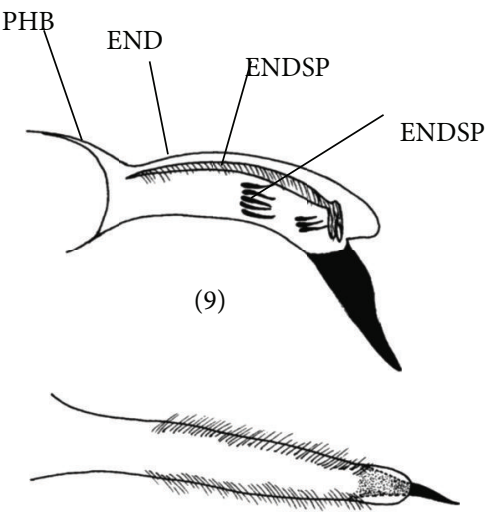

(10)

FIgure 1: Chimarra spp. (1)-(5) Chimarra nigra Kimmins ơ genitalia: (1) left lateral view; (2) dorsal view; (3) inferior appendage ventral view; (4) phallus ventral view; (5) phallus lateral view. (6)-(10) C. butticulata sp. nov. ô genitalia: (6) left lateral view; (7) dorsal view; (8) inferior appendage ventral view; (9) phalllus lateral view; (10) phallus ventral view.

Phallotheca tubular, expanded basodorsally, and sclerotized. Endotheca with basodorsal projection, length not discernable, apically with ventral, large spine-like projection, strongly sclerotized (maybe of phallotheca) in lateral view; a row of comb-like spines laterally visible in ventral view, phallotremal complex not visible, two rows of asymmetrical, small spines visible preapically. 
Diagnosis. C. butticulata sp.n. is allied to C. nepalensis Kimmins [36], C. nahesson Malicky and Chantaramongkol [21], and C. fenestrata Kimmins [36] due to presence of long pointed apically sclerotized lateral lobe of tergum $\mathrm{X}$ in lateral view. Comparatively $C$. butticulata sp.n. is very close to C. fenestrata. However, the shape of segment IX in lateral view; inferior appendages constricted near base and slightly pointed apically as viewed laterally and the mesal lobes of tergum X rounded apically as viewed dorsally make C. butticulata a distinct species. There are marked differences in the shape and number of endothecal spines as well.

Distribution. India: Uttarakhand.

\subsection{Digitata Group}

Chimarra sangtami sp.n. (Figure 2 (11)-(15))

Type material. Holotype. INDIA. ot: Nagaland, Kiphrie, $1200 \mathrm{~m}, 16-\mathrm{v}-2010$, Pandher and Parey, (NPC). Paratype $20 \AA, 3$ 우, collection data the same as that of holotype, (NPC).

Etymology. This species is named after Naga tribe "Sangtam" which inhabits the type district "Kiphire" of Nagaland.

Description. Adult ơ; color in alcohol fuscous, antenna, brownish yellow, wing hyaline, maxillary, and labial palpi pale yellow. Body covered with fuscous pubescence. Length from tip of head to apex of folded forewing $6 \mathrm{~mm}$; antenna shorter than forewing, about $-4 \mathrm{~mm}$ long; maxillary palp $1.50 \mathrm{~mm}$, third segment more than 1.5 times longer than second segment; labial palp $0.90 \mathrm{~mm}$ long. Length of each forewing $5 \mathrm{~mm}$, discoidal cell twice as long as its width; Rs curved, cross vein $m$ proximal to cross veins $s$ and $r-m$; $2 \mathrm{~A}$ obsolete and looped to $1 \mathrm{~A}$; hind wing about $3.25 \mathrm{~mm}$ long.

Male Genitalia (Figure 2 (11)-(15)). Tergum IX short, anterodorsally produced; anterior margin concave, ventrolaterally produced; posterolateral margin almost straight; posteroventral process prominent, wide at base, with acute apex. Preanal appendages each short, oblong, setose, in lateral view; globose in dorsal view. Inferior appendages each dorsally inflected basoventrally, wider at base, constricted mesally, with pointed apex in lateral view; in ventral view, sickle-shaped, curved mesally, pointed apically. Tergum X with sclerotized lateral lobes (with sclerotized dorsal and ventral margins) and separate projecting membranous mesal lobes; each lateral lobe long, dorsally with broad and wedge shaped margin and ventral margin digitate which is curved anterodorsally in lateral view, longer than dorsal margin; each mesal lobe digitate, convergent, bifid at apex in dorsal view. Phallotheca tubular and sclerotized. Endotheca slender, long; length not discernable; one long preapical spine visible in lateral and ventral views; phallotremal complex composed of rod and ring structure, in lateral view C shaped, dorsally with granular area.

Diagnosis. In possession of broad segment IX, long postventral process and upright directed inferior appendage, Chimarra sangtami sp.n. is allied to $C$. gether Malicky [16], C. demeter Malicky [12], and $C$. tawitawi Malicky [8]. However, while in C. sangtami the sclerotized lateral lobes of tergum $\mathrm{X}$ are broad mesally, notched preapically, curved outward, and pointed apically as viewed dorsally whereas in the allied species lateral lobe of tergum $\mathrm{X}$ is very different in shape. Moreover, there is considerable difference in the phallus structure like number and size of endothecal spines and phallotremal sclerite complex.

Distribution. India: Nagaland.

Unplaced Species. This species described below is though very similar to species belonging to tsudai Group (due to presence of multiple sensilla on mesal lobe of tergum $X$ and mesal lobe forming upright digitate projection); however, the presence of well developed ventral process on segment IX in C. gangotriensis sp. $\mathrm{n}$. is an exception as the ventral process is more or less obsolete in the species belonging to tsudai Group.

\section{Chimarra gangotriensis sp.n. (Figure 2 (16)-(20))}

Holotype. India. đ: Uttarakhand, Maneri, 1200 m, 5vi-2009, Pandher and Parey, (NPC). Paratype. 19, collection data the same as that of holotype (NPC).

Etymology. This species is named for the Hindu pilgrim Gangotri on the road through Maneri.

Description. Adult o; color: alcohol dark brown; dorsum of head, black; thorax, black; legs, pale brown; wing hyaline, light yellow. Length from tip of head to apex of folded forewing about $-7.50 \mathrm{~mm}$; maxillary palp $-1.50 \mathrm{~mm}$, third segment about twice the second and subequal to the 5th; labial palp long, about$1 \mathrm{~mm}$. Length of each forewing-6.25 $\mathrm{mm}$; Rs curved; cross vein $m$ in close proximity with $s$ and $r-m$ cross veins; $2 \mathrm{~A}$ with obsolete apex, looped to $1 \mathrm{~A}$ at cross vein a; discoidal cell elongates, more than, 1.75 its width.

Male Genitalia (Figure 2 (16)-(20)). Segment IX short; with reduced tergum, obsolete dorsally, anterodorsally not produced; anteroventrally produced; posterolateral margin almost straight; posteroventral process well developed, wide basally, and pointed at apex. Preanal appendages, each obliquely placed, rounded, setose, globose in dorsal view. Inferior appendages each slightly longer than tergum X, directed posterad, constricted near base, wide and inferior margin tapering towards rounded apex in lateral view; in ventral view broad basally, constricted on outer surface, apically pointed and bears long tuft of setae. Tergum $\mathrm{X}$ with sclerotized 


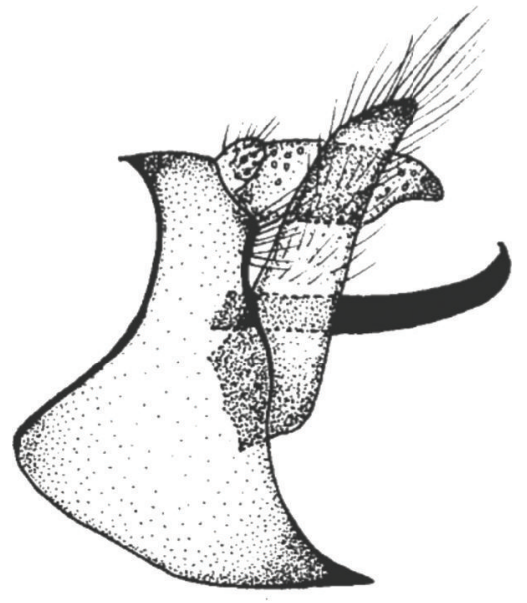

(11)

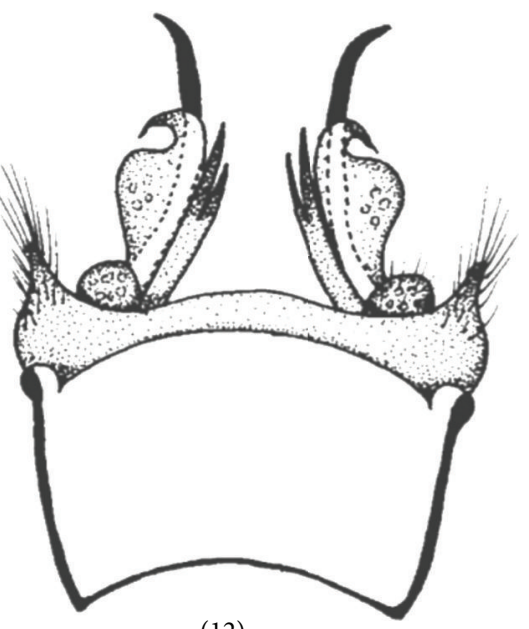

(12)

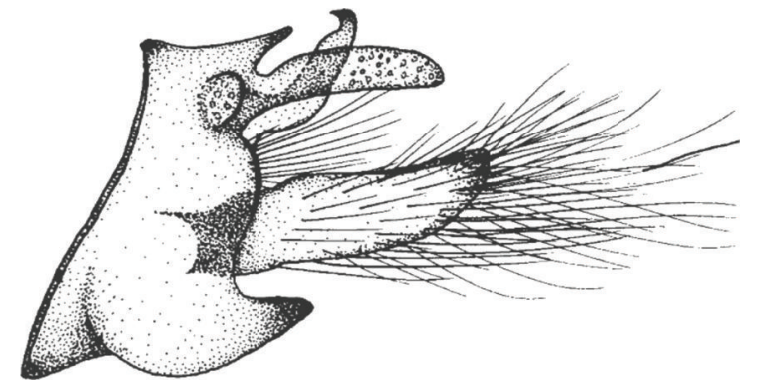

(16)

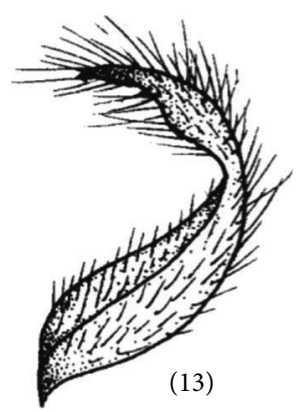

(13)

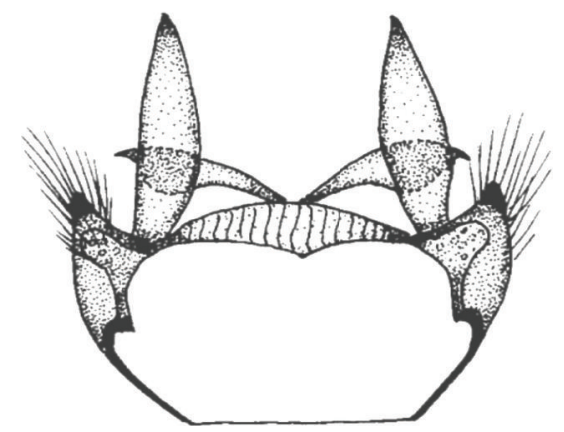

(17)

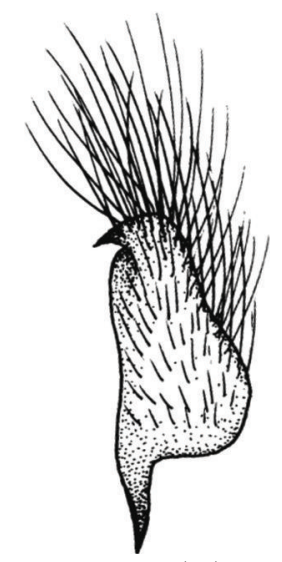

(18)

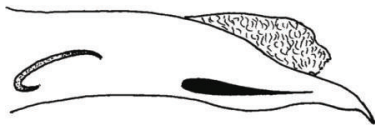

(14)

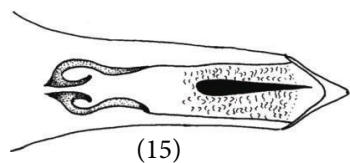

$24 \mathrm{~mm}$

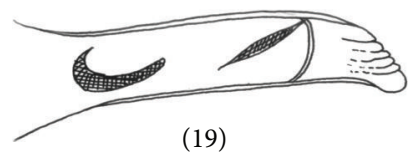

(19)

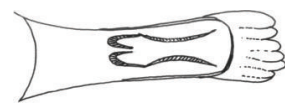

(20)

Figure 2: Chimarra spp. (11)-(15) Chimarra sangtami sp. nov. ơ genitalia: (11) left lateral view; (12) dorsal view; (13) inferior appendage ventral view; (14) phallus lateral view; (15) phallus ventral view. (16)-(20) C. gangotriensis sp. nov. ơ genitalia: (16) left lateral view; (17) dorsal view; (18) inferior appendage ventral view; (19) phallus lateral view; (20) phallus ventral view. (IX: segment 9, PA: preanal appendages, MMLX: membranous mesal lobe of tergum X, SLLX: sclerotized lateral lobe of tergum X, INF: inferior appendage, PVP: posteroventral process, PHB: phallobase, END: endotheca, and ENDSP: endothecal spine). 
lateral and mesolateral lobes and obsolete mesal membranous lobes; each lateral lobe being long, wide, rounded apicoventrally, and bearing multiple sensilla in lateral view; in dorsal view wedgeshaped; each mesolateral lobe posterad directed, curved apicodorsally, and pointed in lateral view; in dorsal view enlarged mesoapically, with pointed, divergent apex. Phallobase tubular and sclerotized. Endotheca long, length not-discernable, with cshaped sclerotized structure probably phallotremal sclerite complex, and apically long spine and endotheca membranous apically.

Diagnosis. This species is allied to C. pontos Malicky, [14], C. semiramis Malicky, [14], and C. oreithyia Malicky, [14] due to presence of long hair like setae on inferior appendages. However, IX sternum with long and broad postventral process; sclerotized lateral lobes of tergum $\mathrm{X}$ pointed in dorsal view make $C$. gangotriensis distinct from allied species. Moreover, c-shaped phallotremal sclerite complex in lateral view is visible in C. gangotriensis whereas no phallotremal sclerite complex is visible in allied species.

Distribution. India: Uttarakhand.

\section{Conflict of Interests}

The authors declare that there is no conflict of interests regarding the publication of this paper.

\section{Acknowledgments}

The authors greatly appreciate the support provided in the form of valuable suggestions by Dr. J.C. Morse, USA, and Dr. H. Malicky, Austria, for literary needs. They are also grateful to Dr. V. V. Ramamurthy, National Coordinator, Network Project on Insect Biosystematics, Indian Agricultural Research Institute, Government of India, New Delhi (NPIB-21-17), for providing funds for this study. Necessary laboratory facilities provided by the Department of Zoology and Environmental Sciences, Punjabi University, Patiala, are thankfully put on record. Thanks are also due to various forest officials, especially Mrs. U. G. Lachungpa, Senior Research Officer, Wildlife Sikkim, Principal Chief Conservator of Forests, and Chief Conservator of Forests and District Forest Officer of Nagaland and Uttarakhand for providing necessary facilities during expeditions. Last but not least they are thankful to the Editor of Advances in Zoology and anonymous reviewers for critically evaluating the paper and providing their valuable suggestions and for their contributions as well.

\section{References}

[1] J. C. Morse, “Trichoptera World Checklist,” 2013, http://entweb. clemson.edu/database/trichopt/index.htm.

[2] F. J. Pictet, Recherches pour servir à l'histoire et l'anatomie des Phryganides, Antoine-Elisée Cherbuliez, Geneva, Switzerland, 1834.
[3] R. J. Blahnik, T. I. Arefina-Armitage, and B. J. Armitage, “The genus Chimarra Stephens (Trichoptera: Philopotamidae) in Vietnam," Insecta Mundi, vol. 229, pp. 1-25, 2012.

[4] R. J. Blahnik, A Revision of the Neotropical Species of the Genus Chimarra, Subgenus Chimarra Trichoptera: Philopotamidae, vol. 59 of Memoirs of the American Entomological Institute, American Entomological Institute, 1998.

[5] H. Malicky, "Neue Köcherfliegen Trichoptera von den Andamanen-Inseln," Zeitschrift der Arbeitsgemeinschaft Österreichischer Entomologen, vol. 30, pp. 97-109, 1979.

[6] H. Malicky, "Köcherfliegen Trichoptera von Sumatra und Nias: Die Gattungen Chimarra Philopotamidae und Marilia Odontoceridae, mit Nachträgen zu Rhyacophila Rhyacophilidae," Mitteilungen der Schweizerischen EntomologischenGesellschaft, vol. 62, pp. 131-143, 1989.

[7] H. Malicky, "Neue asiatische Köcherfliegen (Trichoptera: Philopotamidae, Polycentropodidae, Psychomyiidae, Ecnomidae, Hydropsychidae, Leptoceridae)," Linzer Biologische Beiträge, vol. 25, pp. 1099-1136, 1993.

[8] H. Malicky, "Neue trichopteren aus Nepal, Vietnam, China, von den Philippinen und vom Bismarck-Archipel Trichoptera," Entomologische Berichte Luzern, vol. 31, pp. 163-172, 1994.

[9] H. Malicky, "Neue köcherfliegen trichoptera, insecta aus Vietnam," Linzer Biologische Beiträge, vol. 27, pp. 851-885, 1995.

[10] H. Malicky, "Weitere neue Köcherfliegen-Arten (Trichoptera) aus Asien," Linzer Biologische Beiträge, vol. 29, pp. 217-238, 1997.

[11] H. Malicky, "Köcherfliegen trichoptera von java und Sumatra, mit revision einiger ULMER-typen aus dem Hamburger Museum," Linzer Biologische Beiträge, vol. 30, pp. 795-814, 1998.

[12] H. Malicky, "Einige neue Köcherfliegen aus Sabah, Nepal, Indien und China Trichoptera: Rhyacophilidae, Hydrobiosidae, Philopotamidae, Polycentropodidae, Ecnomidae, Psychomyiidae, Hydropsychidae, Brachycentridae, Odontoceridae, Molannidae," Braueria, vol. 27, pp. 32-39, 2000.

[13] H. Malicky, "Caddisflies from Bardia National Park, Nepal, with a preliminary survey of Nepalese species Insecta, Trichoptera," Entomofauna, vol. 27, pp. 241-264, 2006.

[14] H. Malicky, "Köcherfliegen aus Bhutan Insecta, Trichoptera," Linzer Biologische Beiträge, vol. 39, pp. 475-517, 2007.

[15] H. Malicky, "Köcherfliegen Insecta, Trichoptera aus der Umgebung von Malinau Kalimantan, Borneo, Indonesien," Linzer Biologische Beiträge, vol. 40, pp. 833-879, 2008.

[16] H. Malicky, "Beiträge zur Kenntnis asiatischer Trichopteren," Braueria, vol. 36, pp. 11-58, 2009.

[17] H. Malicky, "Neue Trichopteren aus Europa und Asien," Braueria, vol. 37, pp. 43-48, 2010.

[18] H. Malicky, "Neue Trichopteren aus Europa und Asien," Braueria, vol. 38, pp. 23-43, 2011.

[19] C. Sun and H. Malicky, "22 new species of Philopotamidae Trichoptera from China," Linzer Biologische Beiträge, vol. 34, pp. 521-540, 2002.

[20] H. Malicky and P. Chantaramongkol, "Beschreibung von neuen Köcherfliegen (Trichoptera) aus Thailand und Burma. Arbeiten über thailändische Köcherfliegen Nr. 6," Entomologische Berichte Luzern, vol. 22, pp. 117-126, 1989.

[21] H. Malicky and P. Chantaramongkol, "Neue Trichopteren aus Thailand. Teil 1: Rhyacophilidae, Hydrobiosidae, Philopotamidae, Polycentropodidae, Ecnomidae, Psychomyidae, Arctopsychidae, Hydropsychidae," Linzer Biologische Beiträge, vol. 25, pp. 433-487, 1993. 
[22] H. Malicky and P. Chantaramongkol, "Neue Trichopteren aus Thailand. Teil 2: Rhyacophilidae, Philopotamidae, Polycentropodidae, Ecnomidae, Psychomyidae, Xiphocentronidae, Helicopsychidae, Odontoceridae," Linzer Biologische Beiträge, vol. 25, pp. 1137-1187, 1993.

[23] H. Malicky and P. Chantaramongkol, "Vierzehn neue Köcherfliegen aus Thailand Insecta, Trichoptera. 35. Arbeit über thailändische Köcherfliegen," Linzer Biologische Beiträge, vol. 35, pp. 915-925, 2003.

[24] H. Malicky, P. Chantaramongkol, P. Bunlue et al., "27 neue Köcherfliegen aus Thailand (Insecta, Trichoptera). (36. Arbeit über thailändische Köcherfliegen," Linzer Biologische Beiträge, vol. 36, pp. 287-304, 2004.

[25] N. Banks, "On a collection of neuropteroid insects from the Philippine Islands," Proceedings of the Entomological Society of Washington, vol. 15, pp. 170-180, 1913.

[26] N. Banks, "Bornean neuropteroid insects," Journal of the Malay Museum, vol. 16, pp. 421-426, 1931.

[27] N. Banks, "Philippine neuropteroid insects," Philippine Journal of Science, vol. 63, pp. 125-174, 1937.

[28] R. J. Blahnik, R. W. Holzenthal, and J. Huisman, "Chimarra of Sabah and Sarawak, northern Borneo. (Trichoptera: Philopotamidae)," Tijdschrift voor Entomologie, vol. 152, pp. 109-166, 2009.

[29] S. K. Ghosh and M. Chaudhury, "State fauna series 3: fauna of West Bengal, insecta trichoptera, thysanoptera, neurop tera, hymenoptera, and anoplura," Zoological Survey of India, vol. 8, pp. 1-25, 1999.

[30] H. A. Hagen, "Synopsis der Neuroptera Ceylons," Verhandlungen der Kaiserlich-Königlichen Zoologische-Botanischen Gesellschaft in Wien, vol. 8, pp. 471-488, 1858.

[31] H. A. Hagen, "Synopsis der Neuroptera Ceylons (Pars II)," Verhandlungen der Kaiserlich-Königlichen Zoologisch-Botanischen Gesellschaft in Wien, vol. 9, pp. 199-212, 1859.

[32] C. Hwang, "Descriptions of Chinese caddisflies Trichoptera," Acta Entomologica Sinica, vol. 10, pp. 279-285, 1957.

[33] S. Jacquemart, "Deux trichopteres nouveaux de Thailande," Bulletin de l'Institut Royal des Sciences Naturelles de Belgique, Entomologie, vol. 51, pp. 1-5, 1979.

[34] D. E. Kimmins, "Results of the Oxford University expedition to Sarawak, 1932. Order Trichoptera," The Sarawak Museum Journal, vol. 6, pp. 374-442, 1955.

[35] D. E. Kimmins, "Entomological results from the Swedish expedition 1934 to Burma and British India, Trichoptera the genus Chimarra Stephens Family: Philopotamidae," Arkiv för Zoologi, vol. 11, pp. 52-75, 1957.

[36] D. E. Kimmins, "On the Trichoptera of Nepal," Bulletin of the British Museum (Natural History) Entomology, vol. 15, pp. 3355, 1964.

[37] A. V. Martynov, "On a collection of Trichoptera from the Indian Museum I.," Records of the Indian Museum, vol. 38, no. 3, pp. 239-306, 1935.

[38] S. I. Melnitsky, "Two new species of Chimarra (Trichoptera: Philopotamidae) from Nepal," Braueria, vol. 32, p. 16, 2005.

[39] W. Mey, "Neue Köcherfliegen von den Philippinen Trichoptera," Opuscula Zoologica Fluminensia, vol. 57, pp. 1-19, 1990.

[40] W. Mey, "Beitrag zur Kenntnis der Köcherfliegenfauna der Philippinen, I. (Trichoptera)," Deutsche Entomologische Zeitschrift, vol. 42, no. 1, pp. 191-209, 1995.

[41] W. Mey, "Contribution to the knowledge of the caddisfly fauna of the Philippines, III Insecta: Trichoptera," Entomofauna, vol. 19, pp. 1-32, 1998.
[42] W. Mey, "Die Köcherfliegenfauna des Fan Si Pan Massivs in Nord-Vietnam. 3. Beschreibung weiterer neuer Arten Trichoptera," Opuscula Zoologica Fluminensia, vol. 165, pp. 1-17, 1998.

[43] W. Mey, "Contribution to the knowledge of the caddisfly fauna of the Philippines, V Insecta, Trichoptera," Insecta Koreana, vol. 20, pp. 425-452, 2003.

[44] W. Mey, "Notes on the caddisfly fauna of Lake Matano in Central Sulawesi Insecta, Trichoptera," Beitraege zur Entomologie, vol. 561, pp. 199-212, 2006.

[45] M. E. Mosely, "Chinese Trichoptera: a collection made by Mr. M.S. Yang in Foochow," Transactions of the Royal Entomological Society of London, vol. 92, pp. 343-362, 1942.

[46] L. Navás, "Neue Trichopteren," Konowia Vienna, vol. 1, pp. 37 38, 1922.

[47] L. Navás, "Communicationes entomológicas. 14. Insectos de la India. 4th serie (I)," Revista de la Academia de Ciencias Exactas. Físicas Químicas y Naturales de Zaragoza, vol. 15, pp. 11-41, 1932.

[48] L. Navás, “Tricopteros (familia Filopotamidos)," Broteria, Ciencias Naturais, vol. 1, pp. 118-119, 1932.

[49] J. Oláh, "Seven new Trichoptera from the Gombak River system, Malaysia," Folia Entomologica Hungarica, vol. 54, pp. 93-100, 1993.

[50] J. Oláh and H. Malicky, "New species and new species records of Trichoptera from Vietnam," Braueria, vol. 37, pp. 13-42, 2010.

[51] M. S. Saini, S. H. Parey, M. S. Pandher, and P. Bajwa Bionotes, "Three new species of caddisfly genus Chimarra from Indian Himalaya (Trichoptera: Philopotamidae)," Bionotes, vol. 12, pp. 86-88, 2010.

[52] M. S. Saini, M. S. Pandher, and P. Bajwa, "Addition of two new species to genus Chimarra Stephens Trichoptera: Philopotamidae from Sikkim India," Halteres, vol. 3, pp. 11-15, 2011.

[53] M. S. Saini, H. S. Parey, and M. S. Pandher, "Three new species of genus Chimarra Stephens (Trichoptera: Philopotamidae) from the Indian Himalayas," Biosystematica, vol. 5, pp. 17-24, 2011.

[54] K. A. Johanson and J. Oláh, "Revision of the Fijian Chimarra (Trichoptera Philopotamidae) with description of 24 new species," Zootaxa, no. 3354, pp. 1-58, 2012.

[55] M. S. Pandher and M. S. Saini, "Three new species of the genus Chimarra Stephens, 1829 (Trichoptera: Philopotamidae) from the Indian Himalayas," Polish Journal of Entomology, vol. 81, no. 1, pp. 63-72, 2012.

[56] M. S. Pandher and M. S. Saini, "Seven new species of the genus Chimarra Stephens (Trichoptera: Philopotamidae) from India," Zootaxa, vol. 3478, no. 3, pp. 313-329, 2012.

[57] F. Schmid, “Trichoptères de ceylan," Archiv für Hydrobiologie, vol. 54, pp. 1-173, 1958.

[58] F. Schmid, "Trichoptères du Pakistan. III Hydroptil idae, Philopotamidae, Polycentropodidae," Tijdschrift voor Entomologie, vol. 103, pp. 83-109, 1960.

[59] C. Sun, "Descriptions of three new species of Philopotamidae from China," Braueria, vol. 34, pp. 19-20, 2007.

[60] G. Ulmer, “Zur Kenntniss aussereuropäischer Trichopteren. (Neuer Trichoptern des Hamburger und Stettiner Museums und des zoologischen Instituts in Halle, nebst Beschreibungen einiger Typen Kolenati's und Burmeis ter's)," Stettiner Entomologische Zeitung, vol. 66, pp. 1-119, 1905.

[61] G. Ulmer, "Neuer beitrag zur kenntnis aussereuropäischer Trichopteren," Notes from the Leyden Museum, vol. 28, pp. 1-116, 1906. 
[62] G. Ulmer, "Trichopteren. Collections Zoologiques du Baron Edm," de Selys Longchamps, vol. 6, no. 1, pp. 1-102, 1907.

[63] G. Ulmer, "Trichopteren des Ostens, besonders von Ceylon und Neu-Guinea," Deutsche Entomologische Zeitschrift, vol. 1915, no. 1, pp. 41-75, 1915.

[64] G. Ulmer, "Trichopteren von den Philipp inen und von den Sunda-Inseln," Treubia, vol. 11, pp. 373-498, 1930.

[65] G. Ulmer, "Köcherfliegen (Trichopteren) von den SundaInseln. Teil I.," Archiv für Hydrobiologie, vol. 19, supplement, pp. $1-528,1951$

[66] L. Yang, C. Sun, and W. Yang, "Trichoptera of Tianmu Mountain," in Insects of Tianmu Mountain Nature Reserve, $\mathrm{H}$. Wu, Ed., pp. 505-519, China Forestry Publishing House, Hangzhou, China, 2001.

[67] B.-X. Wang, C. H. Sun, L. Yang, and K.-M. Leng, "Trichoptera," in Insects of Longwangshan Nature Reserve, H. Wu, Ed., pp. 151161, China Forestry Publishing House, Beijing, China, 1998.

[68] R. J. Blahnik and R. W. Holzenthal, "Collection and c uration of Trichoptera, with an emphasis on pinned material," Nectopsyche: Neotropical Trichoptera Newsletter, vol. 1, pp. 8-20, 2004, http://www.entomology.umn.edu/museum/links/news.html.

[69] R. J. Blahnik, R. W. HolzenthaL, and A. Prather, "The lactic acid method for clearing Trichoptera genitalia," in Proceedings of the 12th International Symposium on Trichoptera, J. Bueno-Soria, R. Barba-Álvarez, and B. J. Armitage, Eds., pp. 9-14, The Caddis Press, Columbus, Ohio, USA, 2007.

[70] H. Malicky and P. Chantaramongkol, "Weitere neue Köcherfliegen (Trichoptera) aus Thailand. Arbeit Nr. 20 über thailändische Köcherfliegen," Linzer Biologische Beiträge, vol. 29, no. 1, pp. 203-216, 1997. 

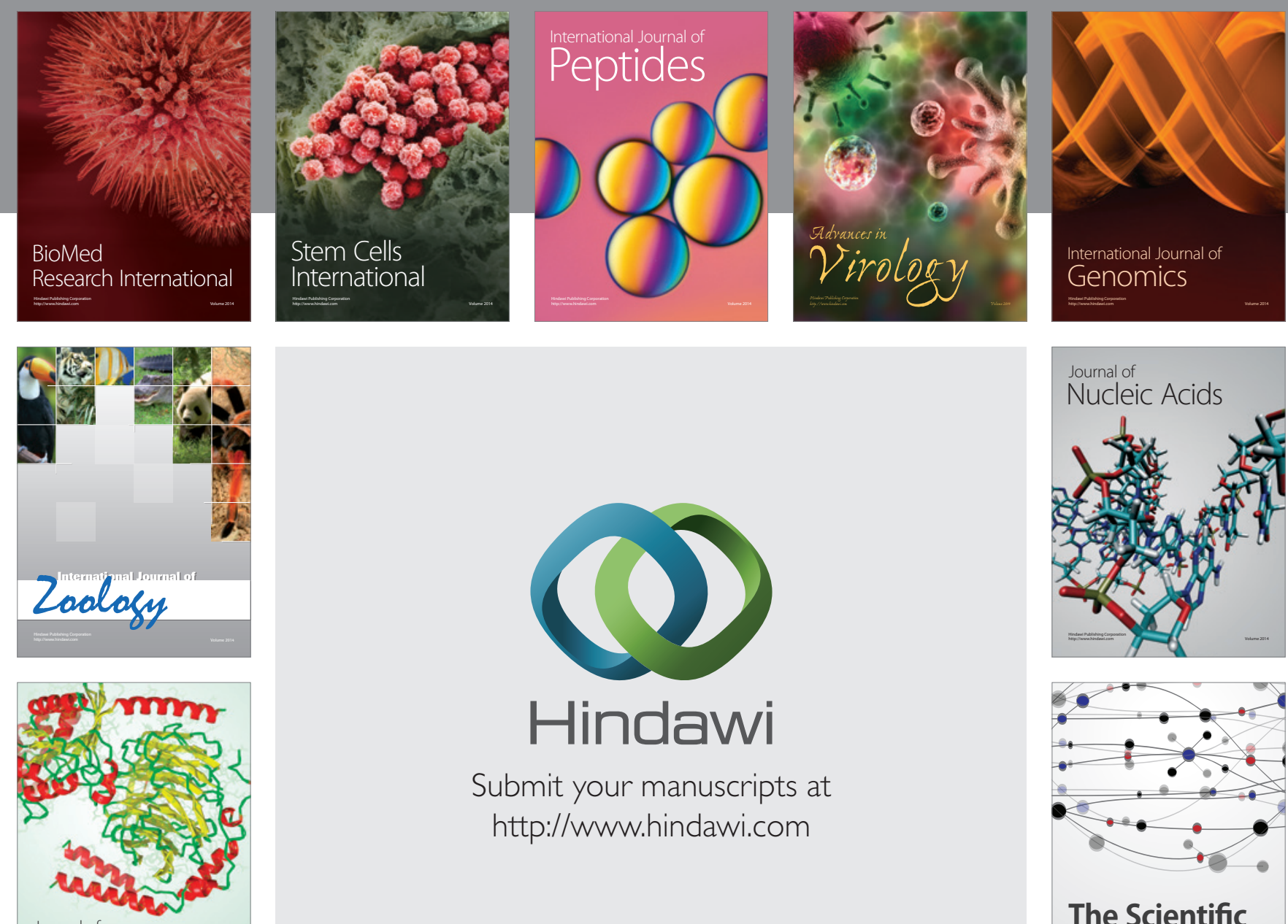

Submit your manuscripts at

http://www.hindawi.com

Journal of
Signal Transduction
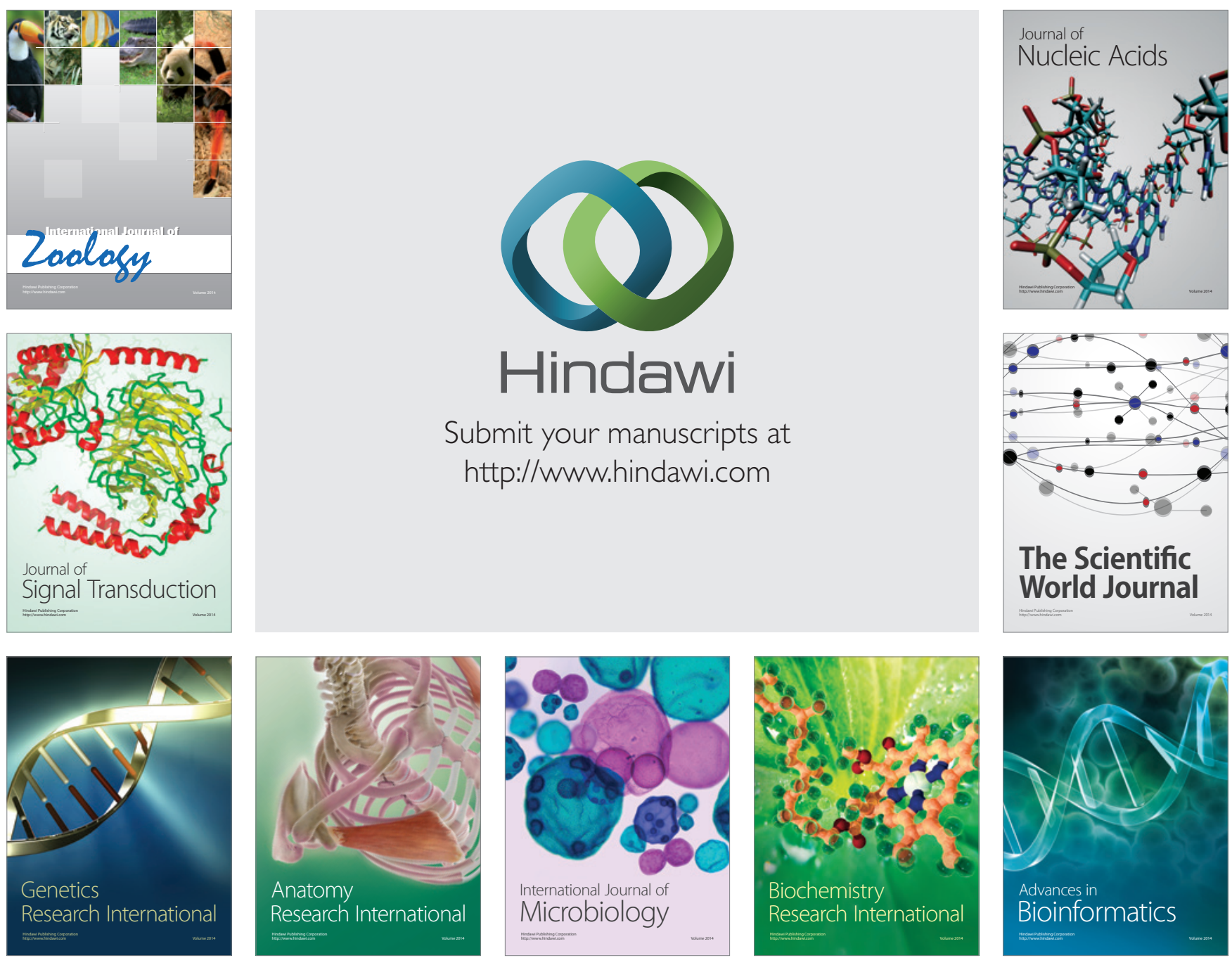

The Scientific World Journal
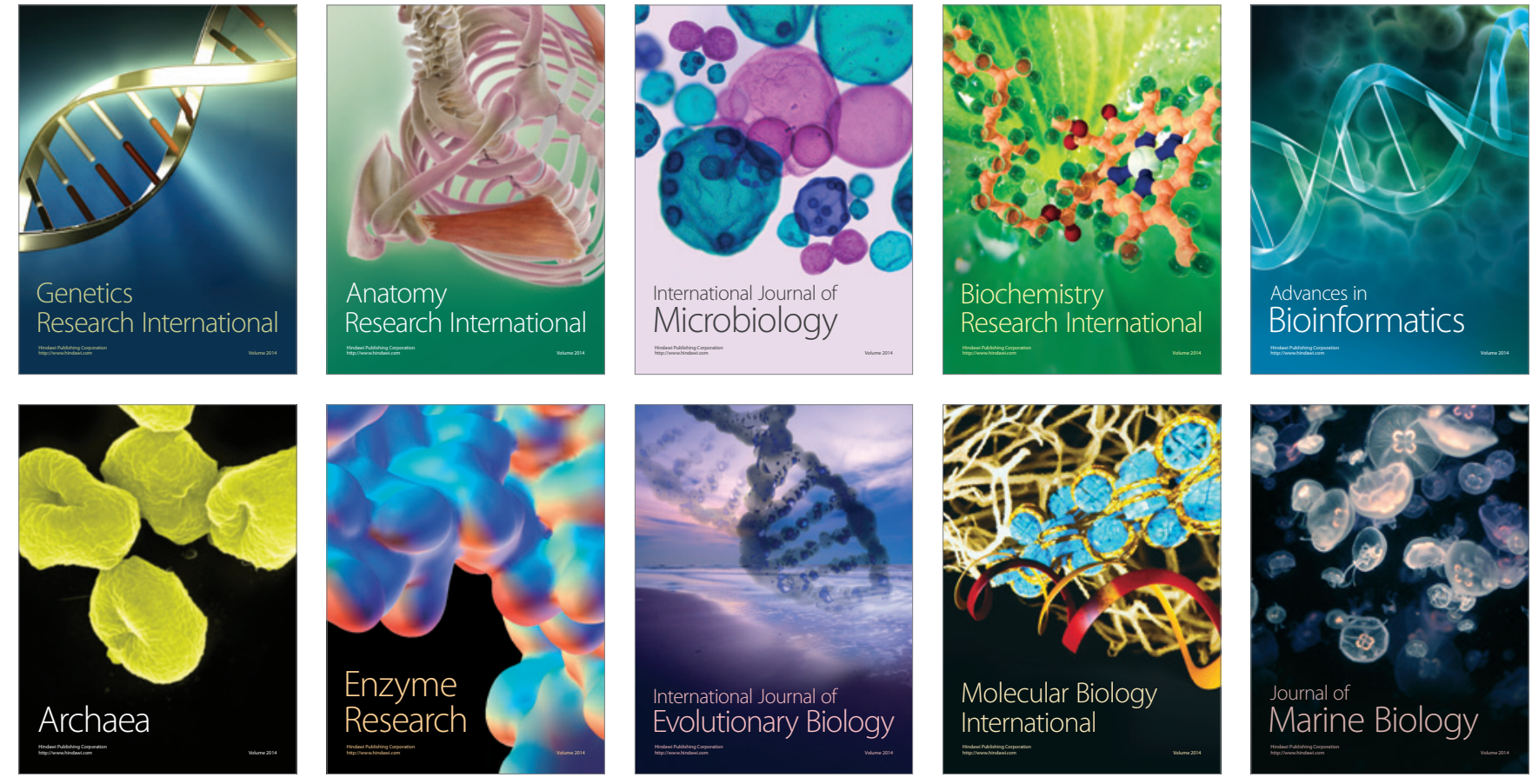